\title{
The Relevance Of The Big Five Model To Students' Adaptation To The Academic Environment Personality and Academic Experiences
}

\author{
Cristian Zanon ${ }^{1}$ \\ Alexandra Araújo ${ }^{2}$ \\ Claudio S. Hutz ${ }^{3}$ \\ ${ }^{1}$ Universidade Federal do Rio Grande do Sul, RS, Brasil \\ http://orcid.org/0000-0003-3822-5275 \\ ${ }^{2}$ Universidade Portucalense Infante D. Henrique, Porto, Portugal \\ https://orcid.org/0000-0003-4345-0856 \\ ${ }^{3}$ Universidade Federal do Rio Grande do Sul, RS, Brasil \\ https://orcid.org/0000-0002-3252-7339
}

\begin{abstract}
The Big Five has been used as a theoretical framework for the evaluation of the $21^{\text {st }}$ century skills and is associated with desirable outcomes. This study evaluates the extent to which the Big Five relates to students' adaptation to the academic environment. Participants were 845 undergraduate students (60.7\% female), aged from 17 to 31 years who answered the Factorial Personality Battery and the Academic Experience Questionnaire. Data reduction analysis at the facet level recovered the Big Five structure and indicated that Extraversion, Neuroticism, and Conscientiousness are, respectively, associated with higher personal, interpersonal, and study related academic adaptation dimensions. Agreeableness and Openness did not cluster with academic dimensions, suggesting lower relevance for academic adaptation in higher education.
\end{abstract}

Key-words: university students; academic experiences; $21^{\text {st }}$ century skills.

\section{A Relevância do Modelo dos Cinco Grandes \\ Para a Adaptação dos Estudantes ao Ambiente Acadêmico}

\section{Resumo}

O Big Five tem sido usado como referencial teórico para a avaliação das habilidades do século 21 e está associado a resultados desejáveis. Este estudo avalia o quanto os Cinco Grandes Fatores se relacionam com a adaptação dos alunos ao ambiente acadêmico. Participaram 845 estudantes de graduação (60,7\% do sexo feminino), com idades entre 17 e 31 anos, que responderam a Bateria de Personalidade Fatorial e o Questionário de Experiência Acadêmica. A análise de redução de dados no nível de faceta recuperou a estrutura dos cinco grandes fatores e indicou que Extroversão, Neuroticismo e Conscienciosidade estão, respectivamente, associados a dimensões de adaptação acadêmica pessoais, interpessoais e relacionadas ao estudo. A Amabilidade e a Abertura não se agruparam com as dimensões acadêmicas, sugerindo menor relevância para a adaptação acadêmica no ensino superior.

Palavras-chave: estudantes universitários; experiências acadêmicas; Habilidades do século XXI. 


\title{
La Relevancia del Modelo de los Cinco Grandes \\ Para la Adaptación de los Estudiantes al Entorno Académico
}

\begin{abstract}
Resumen
The Big Five se ha utilizado como un marco teórico para la evaluación de las habilidades del siglo 21 y se asocia con los resultados deseables. Este estudio evalúa el grado en que los Cinco grandes se relacionan con la adaptación de los estudiantes al entorno académico. Los participantes fueron 845 estudiantes de pregrado (60,7\% mujeres), con edades comprendidas entre 17 y 31 años que respondieron la Batería de Personalidad Factorial y el Cuestionario de Experiencia Académica. El análisis de reducción de datos a nivel de faceta recuperó la estructura de los cinco grandes e indicó que Extraversión, Neuroticismo y Conciencia están, respectivamente, asociados con dimensiones de adaptación académica más personal, interpersonal y relacionada con el estudio. La amabilidad y la apertura no se combinaron con las dimensiones académicas, lo que sugiere una menor adaptación académica de relevancia en la educación superior.
\end{abstract}

Palabras clave: estudiantes universitários; experiencias académicas; Habilidades del siglo 21

The Big Five Model (McCrae \& John, 1992) has served as a theoretical framework for the evaluation of the $21^{\text {st }}$ Century Skills of children and adolescents (Kyllonen, Lipnevich, Burrus, \& Roberts, 2008; Primi, Santos, John, \& de Fruyt, 2016; Primi, Zanon, Santos, de Fruyt, \& John, 2016). These skills are positively related to a series of desirable outcomes in school, including school engagement (Duckworth \& Seligman, 2005; Fredricks \& McColskey, 2012; Zanon, Bastianello, Pacico, \& Hutz, 2014) and healthy and well-succeeded development (Kautz, Heckman, Diris, Weel, \&Borghans, 2014; Saklofske et al., 2012). Thus, personality may play a relevant role in many ways during undergraduate's adaptation to the university environment. This study aims to map the way academic experiences relate to the Big Five Model.

\section{The Big Five, Academic Adaptation and $21^{\text {st }}$ Century Skills}

Becoming an undergraduate student constitutes a challengeable and exciting experience, which thousands of adolescents and young adults start every year. The way people experience the transition to higher education varies considerably and might produce a significant impact in their day-to-day activities and in significant aspects of life related to achievement, mental health, and happiness. Some findings, in the Brazilian context, highlight that some variables might explain individual differences related to how well undergraduate students adapt to the academic environment. For example, social abilities favor student's interaction (Soares, Poube, \& Mello, 2009), high expectations regarding classmate's interaction, career project development and curricular activities engagement are positively related to academic adaptation (Soares, 2014). While, coping strategies focused on problem-solving and social practices development are associated with satisfactory processes of adaptation, strategies focused on emotion and religious thinking were negatively associated with adaptation (Carlotto, Teixeira, \& Dias, 2015). Recent evidence suggests that the beliefs (e.g., self-efficacy) students present about their capacities to deal with college issues contribute to their life satisfaction (Santos, Zanon, \& Ilha, 2019), and that their adaptation to higher education's challenges is related to the overall satisfaction with their experience in university (Santos, Polydoro, Scortegagna, \& Linden, 2013).

Students poorly adapted and engaged in the academic context are more likely to dropout. In fact, Castro and Teixeira, (2013) verified that the main reasons for undergraduates' dropout in Brazil are related to lack of motivation to study topics focused on specific areas and difficulty in relationships with classmates and faculty. Other findings also point out the relevance of social engagement and skills are key components of academic adaptation (Bardagi \& Hutz, 2012; Schleich, Polydoro „\& Santos, 2006; Soares \& Del Prette, 2015; Teixeira, 
Castro, \& Zoltowski, 2012). Therefore, characteristics related to personal and interpersonal dispositions, as well as dedication, persistence, and openness seem to be critical for the experience of Brazilian students' adaptation.

Research suggests that personality is, in fact, significantly related to academic performance (Poropat, 2009; Kappe \& van der Flier, 2012) and adaptation in higher education (Credé \& Niehorster, 2012), which are central indicators of students' success and promotors of persistence. Academic adaptation constitutes an important process for undergraduates' engagement, motivation, emotional well-being, and performance (Beyers \& Goossens, 2002; Lounsbury, Tatum, Chambers, Owens, \& Gibson, 1999; Wintre et al., 2011). In addition, twenty-first century skills, such as self-confidence, friendship development, cooperation, efficient study habits, self-identification with institutional values and facilities, and satisfaction related to a future career, which may be promoted by the undergraduate course, are critical for undergraduate adaptation (see Credé \& Niehorster, 2012, for a through discussion about the topic). While these personal and interpersonal characteristics may be developed before enrolling in university, institutional and career self-identification may constitute more situational processes related to specific lived events during the academic period. If so, part of the academic adaptation process may be previously predicted by personality traits, while other components of adaptation are more contextually-driven.

Regarding the Big Five model (McCrae \& John, 1992), Credé and Niehorster (2012) showed that more extraverted, agreeable, open, conscientious, and emotional stable students present better adaptation to the academic environment, because they are better in making friends, exploring the environment, are more confident, hardworking, and present less anxiety and stress. Despite these very plausible hypotheses, we have found few studies providing support for them (see, Rosin, Zanon, \& Teixeira, 2014), indicating there is a need to further research regarding the associations between personality and adaptation.
Applied psychologists have been using multidimensional instruments to assess undergraduate academic experiences at university in specific areas (e.g., personal, interpersonal, study, career, and institutional) to investigate students' adaptation (Araújo et al., 2014; Araújo et al., 2016). The Student Adaptation to College Questionnaire (SACQ: Baker \&Siryk 1984), for example, is the most internationally used test. In addition, the Academic Experience Questionnaire (QVA: Almeida, Soares, \& Ferreira, 2002; Granado, 2004; Granado, Santos, Almeida, Soares, \& Guisande, 2005) has been used in Portugal and Brazil as an alternative and culturally-appropriate measure of students' experiences in college. Both questionnaires present similar content, but different structures (e.g., the SACQ does not include a dimension of career adaptation). In the Academic Experience Questionnaire, the personal dimension represents emotional maladjustment to the demands of the university environment in terms of feeling anxiety, stress, and confidence. The interpersonal dimension evaluates social adjustment to campus activities, and meeting and making friends. The study factor evaluates the adequacy of study habits, engagement, and academic efforts. The career dimension evaluates attachment and attitudes towards disciplines, the chosen course, and future job demands. Finally, the institutional area evaluates self-identification with values, staff, and facilities found in campus (Almeida et al., 2002). Thus, research relating the QVA with a Big Five instrument in Brazil might produce interesting findings for a national and international audience of personality and counseling psychologists.

This study aims to map the common academic adaptation dimensions into the Big Five structure without imposing any previously expected relations among the variables (e.g., through a principal component analysis). A common practice to study relations among academic adaptation dimensions (in university students) and other variables is through $t$ tests, $A N O V A \mathrm{~s}$, correlations, and multiple regression analysis (Carlotto, Teixeira, \& Dias, 2015; Rosin, Teixeira, \& Zanon, 2013; Santos et al., 2019; Soares et al., 2019). The current study is innovative in this field as 
it uses a different data analysis methodology - principal components analysis - to explore the relations between students' personality and adaptation to higher education.

\section{Method}

\section{Participants and Procedure}

Participants included 845 Brazilian undergraduate students (60.7\% women), aged from 17 to 31 years $(M=21.3, S D$ =3.1) from five universities in Southern Brazil (two public universities and three private universities). The courses of the participants were Administration (4.3\%), Journalism (3.6\%), Veterinary Medicine (16.5\%), Psychology (8.4\%), Marketing (3.2\%), Food Technology (8.5\%), Zootechny (5.5\%), Statistics (1.5\%), Agronomy (11\%), Accounting Sciences (5\%), Geography (2,7\%), Economics (3\%), Special Education (4.4\%), Physical Education (3\%) and others (2\%). Approximately $30 \%$ of students were in the first year, $38 \%$ in the second year, $18 \%$ in the third year, and $14 \%$ in the fourth year.

All participants were invited to participate in the current study in their classrooms, after the teacher in charge assigned part of the class for this activity. Participants were selected according to the convenience criterion and agreed to respond to the questionnaire after being explained the research objectives. Data collection typically required 25-35 min.

Ethical considerations. Approval for this research was obtained from Comitê de Ética da Universidade Federal do Rio Grande do Sul under the CAAE: 2010001. Participation was voluntary and confidentiality and anonymity were guaranteed.

\section{Measures}

\section{Big Five}

The Factorial Personality Battery (FPB; Nunes, Hutz, \& Nunes, 2008) is a self-reported measure with 126 items modeled on the Five Factor Model (McCrae \& John, 1992). Items in the FPB were constructed in the form of sentences that describe the participants' attitudes, beliefs, and feelings. Answers are provided on a 7-point Likert-type scale $(1=$ does not describe me at all; 7 = describes me very well). The FPB showed adequate alpha coefficients for the five factors: Neuroticism $=.89$, Extraversion $=.84$, Agreeableness $=$ .85 , Conscientiousness $=.83$, and Openness $=.74$. Each factor includes the specific facets presented in table 2 .

\section{Academic experience}

The Academic Experience Questionnaire - Reduced version (AEQ-R: Almeida et al., 2002) is a self-reported measure with 55 items that assesses five dimensions of adaptation to university: personal, interpersonal, study, career, and institutional adaptation. Items in the AEQ-R were constructed in the form of sentences that describe the participant's feelings, adequacy, and adaptation to the academic environment. The items are answered on a 5 -point Likert scale $(1=$ does not describe me at all; 5 = describes me very well). The AEQ-R showed adequate alpha coefficients for the five factors: personal $=.83$, interpersonal $=.81$, study $=.78$, career $=.73$, and institutional adaptation $=.71$.

\section{Data Analysis and Results}

\section{Pearson Correlations}

Results in table 1 show that: a) more conscientious students present more favorable experiences in the study and career adaptation dimensions; b) more extraverted students present higher scores in interpersonal, study, and career adaptation dimensions; c) more emotionally stable students present higher scores in the personal, interpersonal, career, and institutional adaptation dimensions (because the scores in this dimension indicate emotional maladaptation, we inverted the scores), d) more agreeable students also present more favorable interpersonal adaptation experiences, and e) Openness only presents a small correlation with study adaptation, which was contrary to our expectations. The Big 
Five inter-factor mean correlation is .18 and the mean dimensions is .22, which indicates relative factor indecorrelation among the academic adaptation experience pendence between both sets of constructs.

Table 1. Correlations among Personality and Academic Experiences

\begin{tabular}{|c|c|c|c|c|c|c|c|c|c|}
\hline Variables & 1. & 2. & 3. & 4. & 5. & 6. & 7. & 8. & 9. \\
\hline 1. $\mathrm{O}$ & - & & & & & & & & \\
\hline 2. $\mathrm{C}$ & .04 & - & & & & & & & \\
\hline 3. E & $.30^{* *}$ & $.17^{* *}$ & - & & & & & & \\
\hline 4. A & -.02 & $.33^{* *}$ & $.15^{* *}$ & - & & & & & \\
\hline 5. $\mathrm{N}$ & -.01 & $-.29^{* *}$ & $-.22^{* *}$ & $-.38^{* *}$ & - & & & & \\
\hline 6. Personal & $-.09^{*}$ & $.08^{*}$ & -.02 & $.07^{*}$ & $-.41^{* *}$ & - & & & \\
\hline 7. Interpersonal & $.08^{*}$ & $.07^{*}$ & $.39^{* *}$ & $.25^{* *}$ & $-.17^{* *}$ & $.11^{* *}$ & - & & \\
\hline .8. Study & .04 & $.34^{* *}$ & $.23^{* *}$ & $.14^{* *}$ & -.01 & $.35^{* *}$ & $.14^{* *}$ & - & \\
\hline 9. Career & $.14^{* *}$ & $.16^{* *}$ & $.20^{* *}$ & $.07^{*}$ & $-.23^{* *}$ & $.23^{* *}$ & $.30^{* *}$ & $.29^{* *}$ & - \\
\hline 10. Institutional & -.01 & $.12^{* *}$ & $.14^{* *}$ & $.17^{* *}$ & $-.13^{* *}$ & .06 & $.36^{* *}$ & $.09^{*}$ & $.28^{* *}$ \\
\hline
\end{tabular}

Note. $\mathrm{O}=$ Openness, $\mathrm{C}=$ Conscientiousness, $\mathrm{E}=$ Extraversion, $\mathrm{A}=$ Agreeableness, $\mathrm{N}=$ Neuroticism $,{ }^{*} p<.05,{ }^{* *} p<.01$

\section{Principal Component Analysis}

Despite the many relations indicating the extent to which the Big Five permeates academic adaptation areas, we identified clusters that present a more parsimonious understanding of the set of variables on a lower level (e.g., personality facets and academic adaptation parcels). The items of each academic experiences (AE) dimension were parceled in groups of 3 or 4 items following their order in the questionnaire. Next, principal component analysis (PCA, with Varimax rotation) with the Big Five facets and AE indicators were run to identify possible clusters of items (Table 2). 
Table 2. Data Reduction of the Big Five Facets and Academic Experiences Indicators through Principal Component Analysis (Varimax Rotated)

\begin{tabular}{|c|c|c|c|c|c|c|}
\hline Variables & Comp. 1 & Comp. 2 & Comp. 3 & Comp. 4 & Comp. 5 & Comp. 6 \\
\hline E4-Gregariousness & .86 & -.04 & -.01 & .05 & .01 & .04 \\
\hline E3-Assertiveness & .71 & -.27 & .33 & .17 & -.03 & .04 \\
\hline E1-Communication & .68 & -.39 & -.01 & -.01 & -.09 & .02 \\
\hline E2-Excitement Seeking & .61 & .21 & .02 & -.02 & -.50 & -.03 \\
\hline Qinter3 & .54 & .06 & .06 & .01 & .16 & .08 \\
\hline Qinter1 & .50 & -.10 & .01 & .04 & -.11 & .13 \\
\hline A3-Tender-Mindedness/Altruism & .50 & .30 & .26 & .09 & .48 & .05 \\
\hline Qinter2 & .50 & -.12 & -.04 & .36 & .15 & .01 \\
\hline N1-Vulnerability & -.18 & .79 & .01 & -.05 & -.04 & -.17 \\
\hline Qpess1 & .02 & .67 & .05 & -.09 & -.06 & .11 \\
\hline N3-Lack of Energy & .03 & .64 & -.47 & -.03 & -.10 & -.03 \\
\hline N2-Volitility & .02 & .62 & -.04 & -.09 & -.51 & -.01 \\
\hline N4-Depression & -.29 & .62 & -.10 & -.21 & -.30 & .08 \\
\hline Qpess2 & .07 & .59 & .14 & .29 & .10 & -.16 \\
\hline Qpess3 & -.02 & .50 & -.12 & -.06 & .20 & -.03 \\
\hline C3-Self-Discipline & .10 & .13 & .78 & .04 & .07 & .01 \\
\hline C1-Competence & .41 & -.27 & .64 & .23 & .01 & .12 \\
\hline Qestud3 & -.13 & -.04 & .58 & .06 & .12 & -.05 \\
\hline Qestud1 & .00 & .30 & .55 & -.17 & .03 & .04 \\
\hline Qestud2 & .21 & -.08 & .51 & .11 & .07 & -.11 \\
\hline Qcursol & .05 & -.21 & .05 & .72 & -.07 & -.05 \\
\hline Qcurso3 & .07 & -.07 & .17 & .72 & -.01 & .08 \\
\hline Qinstit1 & .05 & -.03 & .08 & .65 & .08 & -.21 \\
\hline Qcurso2 & .06 & -.09 & .10 & .60 & .01 & .32 \\
\hline Qinstit2 & .01 & -.04 & .10 & .32 & .15 & -.15 \\
\hline A2-Compliance/Straightforwardness & -.13 & -.07 & .34 & .02 & .65 & -.24 \\
\hline A3-Trust & .27 & -.39 & -.15 & .02 & .60 & -.08 \\
\hline C2-Deliberation/Dutifulness & -.14 & .06 & .37 & .12 & .51 & .27 \\
\hline O2-Values & .11 & .19 & .01 & .04 & -.08 & .67 \\
\hline O1-Ideas & .14 & -.28 & -.03 & -.14 & .09 & .62 \\
\hline O3-Actions & .41 & .14 & -.10 & -.10 & -.08 & .40 \\
\hline Eigenvalue & 6.0 & 3.5 & 2.5 & 1.8 & 1.5 & 1.3 \\
\hline Variance explained (\%) & 19.4 & 11.2 & 8.0 & 5.8 & 4.8 & 4.2 \\
\hline
\end{tabular}


The best statistical and theoretical solution found $(\mathrm{KMO}=0.85 ;$ and significant Bartlett's test $-p<.001)$ indicated six factors with an eigenvalue above 1 , that explained $53.3 \%$ of the total variance (table 2). PCA successfully identified the Big Five structure of personality. Only two facets did not present the expected highest loadings on the correspondent factor (e.g., A3-TenderMindedness/Altruism loaded higher on Extraversion and C2-Deliberation/Dutifulness loaded higher on Agreeableness). The first identified component clustered Extraversion facets and interpersonal indicators of adaptation - this component also had loadings from other factors (e.g., A3-Tender-Mindedness/Altruism, C1Competence, and O3-Actions). The second component clustered Neuroticism facets and personal indicators of adaptation. The third component was composed by Conscientiousness facets and indicators of study adaptation - this component also had an inverse loading on Neuroticism (e.g., N3-Lack of Energy). The fourth component clustered indicators of institution and career adaptation (only one indicator of institution adaptation presented a loading lower than .40). The fifth component clustered the Agreeableness facets, but also had indicators from other factors (e.g., R2-Deliberation/Dutifulness, N2Volitility (inverse), and E2-Excitement Seeking). The sixth component was composed solely by the Openness facets.

\section{Discussion}

In the current study, we evaluated the extent to which the Big Five model relates to undergraduates' adaptation to the academic environment. Our findings support theoretical expectations about the importance of personality for academic adaptation (Credé \& Niehorster, 2012), except for Openness, which only presented a small correlation with the study adaptation dimension. Although previous studies have already asserted the importance of personality for academic success and emotional adjustment in college (Kappe \&van der Flier, 2012; Poropat, 2009; Saklofske et al., 2009), our study is innovative in observing the relationship between personality structure and specific aspects of students' academic experiences that are relevant for academic adaptation.

Data reduction analysis indicated a solution that recovers the Big Five model clustering the expected personality factors with academic adaptation dimensions: a) Extraversion and interpersonal experiences, b) Neuroticism and personal experiences, and c) Conscientiousness and study experiences. These associations are in accordance with previous findings (Bardagi \& Hutz, 2012; Soares, Poube, \& Mello, 2009; Soares, 2014). The three remaining components did not group personality and academic experiences, although two of them recovered independently the Agreeableness and Openness personality factors, providing evidence of Big Five replicability in Brazil. The last extracted component was composed by the experiences related to career and institution adaptation.

Career and institutional experiences seem to constitute a more situational personality-independent component. Their inter-relations suggest that students more satisfied with the university values, staff, and facilities are more likely to develop a more favorable career perspective and attitude, which might reduce dropping out (Castro and Teixeira, (2013). Nevertheless, the negative correlations found between Neuroticism and career and institutional adaptation dimensions indicate that less emotional stable students may experience less satisfactory experiences in these areas. This might occur because students with higher neuroticism are more likely to use coping strategies focused on emotions to deal with day-to-day situations, instead of strategies focused on problem-solving, and this approach can enhance negative affects, rumination, suffering, and, ultimately, impair academic adaptation (Carlotto, Teixeira, \& Dias, 2015; Rosin, Zanon, \& Teixeira, 2014).

Agreeableness and Openness did not integrate academic dimensions in the six-component model, suggesting a certain academic independency. However, these factors may contribute to academic adaptation through the 
improvement of social support and curiosity (Credé \& Niehorster (2012; Rosin, Zanon, \& Teixeira, 2014; Soares $\&$ Del Prette, 2015) - aspects not contemplated in our evaluation. Future studies may address these possibilities.

This paper is not free from limitations. Our convenience sample restricts the generalizability of our results and limits our understanding about the academic adaptation for specific courses and periods in college. For example, because we have students from more than 20 courses spread from the first to the fourth year, ours results do not allow us to understand which group may struggle more in adapting to the university environment. Future investigations comparing students' courses and academic years might contribute with relevant information to the understanding of the process and to interventions aiming to increase academic adaptation (Porto \& Soares, 2017). On the other hand, we believe, the diversity our sample presents contributions with high variability in the variables of interest $-\mathrm{a}$ desirable condition to run reduction procedures such as principal component analysis, in order to obtain more stable estimates.

In sum, this set of results suggests the Big Five Model may constitute, in part, a theoretical framework to identify some predictors of academic experiences. Future studies relating the Student Adaptation to College Questionnaire (or other multidimensional instruments) and Big Five measures may provide further support for our findings in a broader international context. Selfdiscipline, communication, enthusiasm, and emotional stability, for example, constitute part of the $21^{\text {st }}$ century skills - a set of competences that predicts desirable outcomes through life (Kautz et al., 2014). Our findings constitute further evidence they are also associated with some areas of the academic adaptation.

\section{Conclusion}

The way university students experience their life in the academic environment might contribute (or not) for their adaptation - which might enhance engagement, grades, and overall well-being. Our research is the first to investigate how academic adaptation dimensions are mapped onto the Big Five framework without imposing any expected relationships among the variables, as other investigations have been doing through correlational designs and multiple regressions. Our main results indicate that adaptation to the academic context might be highly favored (or unfavored) by personality factors (e.g., extraversion, neuroticism, and conscientiousness). These findings suggest intrinsic variables of personality play a relevant role in the way students deal with the many challenges associated to their transition to higher education, and therefore may be used in psychoeducational assessments and interventions as predictors of students transition and adaptation to higher education.

\section{References}

Almeida, L. S., Soares, A. P. C. \& Ferreira, J. A. (2002). Questionário de Vivências Acadêmicas (QVA-r): Avaliação do ajustamento dos estudantes universitários. AvaliaçãoPsicológica, 2, 81-93.

Araújo, A. M., Almeida, L. S., Ferreira, A. J., Santos, A. A., Noronha, A. P. P., \& Zanon, C. (2014). Questionário de adaptação ao ensino superior (QAES): Construção e validação de um novo questionário. Psicologia, Educação e Cultura, XVIII, 131-145. https://doi. org/10.1037/t59929-000

Araújo, A. M., Santos, A. A., Noronha, A. P. P., Zanon, C., Ferreira, A. J., Casanova, J. R., \& Almeida, L. S. (2016). Dificuldades antecipadas de adaptação ao ensino superior: Um estudo com alunos do primeiro ano. Revista de Estudios e Investigación en Psicología y Educación, 3, 102-111. doi: 10.17979/reipe.2016.3.2.1846 https://doi.org/10.17979/reipe.2016.3.2.1846

Baker, R. W., \& Siryk, B. (1984). Measuring adjustment to college. Journal of Counseling Psychology, 31, 179-189. doi: 10.1037/0022-0167.31.2.179 https://doi. org/10.1037//0022-0167.31.2.179 
Beyers, W., \& Goossens, L. (2002). Concurrent and predictive validity of the Student Adaptation to College Questionnaire in a sample of European freshman students. Educational and Psychological Measurement, 63(3), 527-538. doi: 10.1177/00164402062003009 https:// doi.org $/ 10.1177 / 00164402062003009$

Credé, M., \& Niehorster, S. (2012). Adjustment to college as measured by the StudentAdaptation to College Questionnaire: A quantitative review of its structure and relationships with correlates and consequences. Educational Psychological Review, 24, 133-165. doi: 10.1007/s10648-011-9184-5 https://doi.org/10.1007/ s10648-011-9184-5

Duckworth, A. L., \& Seligman, M. E. P. (2005). Selfdiscipline outdoes IQ predicting academic performance in adolescents. Psychological Science, 16, 939-944.doi: 10.1111/j.1467-9280.2005.01641.x https://doi.org/10.1111/ j.1467-9280.2005.01641.x

Fredricks, J., \& McColskey, W. (2012). The measurement of student engagement: A comparative analysis of various methods and student self-report instruments. In S. L. Christenson, A. L. Reschly, \& C. Wylie (Eds.), Handbook of research on student engagement (pp. 763782): Springer US. doi: 10.1007/978-1-4614-2018-7_37 https://doi.org/10.1007/978-1-4614-2018-7_37

Granado, J. I. F. (2004). Vivência acadêmica de universitários brasileiros: Um estudo de validade e precisão do QVA-r. Unplublished Dissertation, Universidade São Francisco, Itatiba: Brazil.

Granado, J. I. F., Santos, A. A. A., Almeida, L. S., Soares, A. P., \& Guisande, M. A. (2005): Integração académica de estudantes universitários: Contributos para a adaptação e validação do QVA-r no Brasil. Psicologia e Educação, IV(2), 31-41.

Kappe, R., \& van der Flier, H. (2012). Predicting academic success in higher education: What's more important than being smart? European Journal of Psychology of Education, 27, 605-619. doi: 10.1007/s10212-011-0099-9 https://doi.org/10.1007/s10212-011-0099-9

Kautz, T., Heckman, J. J., Diris, R., Weel, B., \& Borghans, L. (2014). Fostering and measuring skills: Improving cognitive and non-cognitive skills to promote lifetime success. OECD Education Working Papers, No. 110. OECD Publishing. doi: 10.1787/5jxsr7vr78f7-en https://doi.org/10.3386/w20749

Kyllonen, P. C., Lipnevich, A. A., Burrus, J., \& Roberts, R. D. (2008). Personality, motivation, and college readiness: A prospectus for assessment and development. Non printedtecnichal report. Educational Testing Service, Princeton. https://doi.org/10.1002/ets2.12004

Lounsbury, J. W., Tatum H. E., Chambers, W., Owens, K. S., \& Gibson, L. W. (1999). An investigation of career decidedness in relation to 'Big Five' personality constructs and life satisfaction. College Student Journal, 33(4), 646-652.

McCrae, R. R., \& John, O. P. (1992). An introduction to the five-factor model and its applications. Journal of Personality, 60(2), 175-215. doi: 10.1111/j.1467-6494.1992. tb00970.x https://doi.org/10.1111/j.1467-6494.1992. tb00970.x

Nunes, C. H. S. S., Hutz, C. S., \& Nunes, M. F. O. (2008). Bateria Fatorial de Personalidade (BFP). Manual Técnico, São Paulo: Casa do Psicólogo.

Poropat, A. E. (2009). A meta-analysis of the five-factor model of personality and academic performance. Psychological Bulletin, 135, 322-338.doi: 10.1037/ a0014996. https://doi.org/10.1037/a0014996

Primi, R., Santos, D., John, O. P., \& de Fruyt, F.(2016). Development of an inventory assessing social and emocional skills in Brazilian youth. European Journal of Psychological Assessment, 32(1), 5-16. doi: 10.1027/10155759/a000343. https://doi.org/10.1027/1015-5759/a000343

Primi, R., Zanon, C., Santos, D. de Fruyt, F., \& John, O. P. (2016). Anchoring vignettes: Can they make adolescent self-report of socio-emotional skills more reliable, discriminant, and criterion valid?, European Journal of Psychological Assessment, 32(1), 39-51.doi: 10.1027/1015-5759/a000336. https://doi.org/10.1027/1015$\underline{5759 / \mathrm{a} 000336}$

Rosin, A. B., Zanon, C., \& Teixeira, M. A. P. (2014). Bem-estar subjetivo, personalidade e vivências acadêmicas em estudantes universitários. Interação em Psicologia, 1(18), 1-12. https://doi.org/10.5380/psi. v18i1.27634 
Saklofske, D. H., Austin, E. J., Mastoras, S. M., Beaton, L., \& Osborne, S. E. (2012). Relationships of personality, affect, emotional intelligence and coping with student stress and academic success: Different patterns of association for stress and success. Learning and Individual Differences, 22(2), 251-257. doi: 10.1016/j.lindif.2011.02.010 https://doi.org/10.1016/j. $\underline{\text { lindif.2011.02.010 }}$

Santos, A. A. A., Polydoro, S. A. J., Scortegagna, S. A., \& Linden, M. S. S. (2013). Integração ao ensino superior e satisfação acadêmica em universitários. Psicologia: Ciência e Profissão, 33(4), 780-793. doi: 10.14417/ap.911 https://doi.org/10.1590/s1414-98932013000400002

Soares, A. B., \& Del Prette, Z. A. P. (2015). Habilidades sociais e adaptação à universidade: Convergências e divergências dos constructos. Análise Psicológica, 33(2), 139-151. https://doi.org/10.14417/ap.911

Wintre, M. G., Dilouya, B., Pancer, M. M., Pratt, M. W., Birnie-Lefcovitch, S., Polivy, J., \& Adams, G. (2011). Academic achievement in first-year university: Who maintains their high school average? Higher Education, 62(4), 467-481. doi: 10.1007/s10734-010-9399-2 https:// doi.org/10.1007/s10734-010-9399-2

Zanon, C., Bastianello, M. R., Pacico, J. C., Hutz, C. S. (2014). The importance of personality and parental styles on optimism in adolescents. The Spanish Journal of Psychology, 17, 1-7. doi:10.1017/sjp.2014.49 https:// doi.org/10.1017/sjp.2014.49

Recebido em: 03/08/2018

Aceito em: 25/07/2019

Publicado em: $\mathrm{xx} / \mathrm{x} / \mathrm{xxxx}$

Endereço para correspondência: Cristian Zanon

(Rua Ramiro Barcelos, 2600 - Térreo - Cep 90035003; (51)3308 5261; crstn.zan@gmail.com).

\section{Nome: Cristian Zanon.}

E-mail: crstn.zan@gmail.com

Titulação Acadêmica: Doutor em Psicologia

Afiliação Institucional: Universidade Federal do Rio

Grande do Sul (UFRGS)

\section{Nome: Alexandra Araújo}

E-mail: alexandra.araujom@gmail.com

Titulação Acadêmica: Doutora em Psicologia

Afiliação Institucional: Universidade Portucalense

Infante D. Henrique

\section{Nome: Claudio S. Hutz}

E-mail: claudio.hutz@gmail.com

Titulação Acadêmica: Doutor em Psicologia

Afiliação Institucional: Universidade Federal do Rio Grande do Sul (UFRGS) 